KONSTRUKTIVISME, Vol. 8, No. 1, Januari 2016

p-ISSN: 1979-9438, e-ISSN: 2445-2355

FKIP Universitas Islam Balitar, Blitar

Web: konstruktivisme.unisbablitar.ejournal.web.id

\title{
PENGEMBANGAN MODEL KURIKULUM \\ PENDIDIKAN BAHASA INGGRIS BERBASIS KKNI
}

\author{
Imroatus Solikhah \\ IAIN Surakarta \\ JI. Pandawa, Pucangan, Surakarta \\ Email: ratu.shyma@yahoo.com
}

\begin{abstract}
The objective of this study is to promote model English language education curriculum in reference to Indonesian Qualifiation Framework (IQF), practically KKNI-Based English Curriculum. Curriculum evaluation implementing content analysis was used and qualitative approach that involved document analyses, interview, discussion, and workshop was utilized for data collection. This study discovers that alignment of terms of CBC and KKNI-Based Curriculum is required, learning outcomes for institution and course learning outcomes are formulated prior to devise list of courses and course distribution. Admittedly, credits of the whole program and semesterly credits distribution are successivey determined. The recent curriculum has put its quality assurance and it might be applicable to adopt.
\end{abstract}

Key-words: KKNI, learning outcomes, curriculum, competency.

\begin{abstract}
Abstrak
Tujuan penelitian ini ialah pengembangan model kurikulum Pendidikan Bahasa Inggris dalam konteks Kerangka Kualifikasi Nasional Indonesia (KKNI), yang secara praktis disebut Kurikulum Bahasa Inggris Berbasis KKNI. Penelitian ini menggunakan design analisis isi berpijak pada evaluasi kurikulum berdasarkan pendekatan kualitatif. Data dikumpulkan dari dokumen, wawancara, diskusi dan workshop. Penelitian menemukan bahwa penyepadanan terminologi dalam KBK dan KKNI diperlukan untuk kerangka kurikulum, learning outcomes lembaga dan learning outcomes mata kuliah harus lebih dulu dirumuskan sebelum penyusunan daftar mata kuliah dan distribusinya. Selanjutnya, jumlah kredit seluruh program and kredit per semester ditentukan. Kurikulum hasil pengembangan ini sudah mempertimbangkan jaminan kualitas dan bisa diadopsi untuk kegunaan Prodi.
\end{abstract}

Kata-kunci: KKNI, capaian, kurikulum, kompetensi.

Pengembangan kurikulum pendidikan tinggi merujuk pada Kerangka Kualifikasi Nasional Indonesia (KKNI) saat ini sedang menjadi perhatian khusus di setiap PT. Upaya perumusan telah dan sedang 
Solikhah, Imroatus. 2016. Pengembangan Model Kurikulum

Pendidikan Bahasa Inggris Berbasis KKNI. Konstruktivisme, 8(1): 20-36.

dilakukan oleh setiap PT. Rumusan kurikulum tersebut pada umumya bersifat tentatif karena masih uji-coba.

KKNI adalah suatu rujukan nasional untuk meningkatkan mutu dan daya saing bangsa Indonesia di sektor SDM melalui capaian kualifikasi SDM yang dihasilkan oleh sistem pendidikan, sistem pelatihan kerja nasional, dan sistem penilaian kesetaraan pembelajaran (Mendiknas, 2010:i). KKNI disyahkan berdasarkan Perpres No. 8 Tahun 2012. Dengan diundangkannya $\mathrm{KKNI}$, berarti semua kurikulum wajib diperbarui menyesuaikan dengan KKNI.

Kerangka Kualifikasi Nasional berkembang pesat dalam lima tahun terakhir dan banyak negara meratifikasi aturan mengikuti ketentuan dalam $\mathrm{KKN}$ tersebut. KKN dianggap sebagai solusi berbagai masalah sistem pendidikan dan pelatihan. Lebih dari 100 negara merumuskan KKN sendiri dengan cara mengadopsi atau mengembangkan KKN dari negara lain. KKN dipandang sebagai alat kebijakan khusus untuk reformasi dan pengembangan pendidikan yang akan meningkatkan level kemampuan, meningkatkan produktifitas pekerja di pasar kerja, dan memberi kontribusi pada pertumbuhan ekonomi. Aspek kunci agenda KKN ialah keterkaitan antara institusi yang memberi layanan pendidikan dan pelatihan dan kualifikasi yang diperoleh bersifat mutlak (Allais, D, 2011:107).

Kehadiran KKNI berarti juga program untuk mengadakan evaluasi kurikulum. Evaluasi kurikulum didefinisikan sebagai proses yang sistematis untuk mengumpulkan, menganalisis dan menentukan informasi mengenai aspek kurikulum untuk menentukan kelemahan dan perbaikan kurikulum tersebut. Evaluasi kurikulum bisa dilakukan dalam skala kecil maupun besar, mulai dari isi kurikulum, bahan ajar, pembelajaran di kelas, dan buku teks. Titik tekan evaluasi kurikulum ialah pada rumusan tujuan pembelaharan, kompetensi, standar kompetensi, dan rancangan perangkat pembelajaran yang merujuk pada kurikulum tersebut (Salim, 2012; Budiharso, 2015).

Artikel ini bertujuan menerapkan KKNI dalam pengembangan kurikulum Prodi Pendidikan Bahasa Inggris jenjang Sarjana. Pengembangan dimulai dengan rumusan learning outcomes, pemilihan kelompok mata kuliah, dan pengembangan kurikulum dalam satu jenjang.

Program sarjana menurut KKNI ialah Kualifikasi 6, dan memiliki hak dan tanggungjawab berikuti:

1) Mampu mempublikasikan hasil tugas akhir atau karya/desain/seni/model yang dapat diakses oleh masyarakat akademik.

2) Mampu bertanggungjawab atas pekerjaan di bidang keahliannya secara mandiri dan dapat diberi tanggungjawab atas pencapaian hasil kerja institusi atau organisasi dengan mengutamakan keselematan dan keamanan kerja.

3) Mampu mengambil keputusan yang tepat dalam melakukan supervisi dan evaluasi terhadap pekerjaan yang menjadi tanggungjawabnya.

4) Mampu mengelola pembelajaran diri sendiri.

5) Mampu mengkomunikasikan informasi dan ide melalui berbagai media kepada masyarakat sesuai dengan bidang keahliannya.

6) Mampu mengembangkan dan memelihara jaringan kerja. 
FKIP Universitas Islam Balitar, Blitar

Web: konstruktivisme.unisbablitar.ejournal.web.id

Adapun jenjang Kualifikasi 6 menurut KKNI disajikan berikut ini:

Tabel 1. Jenjang Kualifikasi 6 untuk Program Sarjana dalam KKNI

\begin{tabular}{ll}
\hline No & Deskripsi Spesifik \\
\hline 1 & Parameter 1: Keterampilan Kerja \\
& Mampu mengaplikasikan bidang keahliannya dan memanfaatkan ilmu \\
& pengetahuan, teknologi, dan/atau seni pada bidangnya dalam \\
penyelesaian masalah serta mampu beradaptasi terhadap situasi \\
yang dihadapi.
\end{tabular}

Pengembangan Kurikulum berbasis $\mathrm{KKNI}$ dengan sendirinya harus memperhatikan kurikulum sebelumnya, yaitu Kurikulum Berbasis Kompetensi (KBK). Beberapa ketentuan penyusunan kurikulum masih tetap mengacu pada SK Mendiknas No. 232 Tahun 2000 dan SK Mendiknas No. 045 Tahun 2002 tentang Pedoman Penyusunan Kurikulum Pendidikan Tinggi. Beberapa hal yang perlu diperhatikan antara lain: (1) jumlah sks jenjang sarjana ialah 144-160 sks, (2) jenjang sarjana bisa diselesaikan dalam 7 semester, (3) kelompok mata kuliah yang menunjukkan elemen kompetensi ada lima katagori: landasan kepribadian, keilmuan dan keterampilan, keahlian, perilaku berkarya, dan berkehidupan bermasyarakat.

Nomenklatur yang digunakan dalam KBK untuk pengelompokan elemen kompetensi menurut SK Mendiknas No. 232 Tahun 2000 dan SK Mendiknas No. 045 Tahun 2002 ialah: (1) Mata kuliah pengembangan kepribadian (MKK), (2) Mata kuliah Keilmuan dan Keterampilan (MKK), (3) Mata kuliah Keahlian Berkarya (MKB), (4) Mata kuliah perilaku berkarya (MPB), dan (5) Mata kuliah berkehidupan bermasyarakat (MBB). Dalam $\mathrm{KKNI}$, istilah kelompok mata kuliah disebut dengan kelompok kajian. Adapun pengelompokkan menurut bidang kajian dalam KKNI ialah: (1) Kajian Pengembangan Kepribadian (KPK), (2) Kajian Keterampilan Kerja (KKK), (3) Kajian Keilmuan dan Pengetahuan (KKP), (4) Kajian Metode dan Tingkat Penguasaan (KMP), dan (5) Kajian Kemampuan Manajerial (KKM) (Mendiknas, 2010:18).

Merujuk pada istilah yang digunakan dalam KBK dan KKNI tersebut, berikut disajikan penyepadanan istilah yang dibuat oleh Solikhah 
Pendidikan Bahasa Inggris Berbasis KKNI. Konstruktivisme, 8(1): 20-36.

(2015a:161) dalam KBK dan KKNI yang dikembangkan untuk kurikulum Pendidikan Bahasa Inggris jenjang Sarjana atau Kualifikasi 6.

Tabel 2. Proporsi SKS Kurikulum Sarjana Pendidikan Bahasa Inggris

\begin{tabular}{|c|c|c|c|}
\hline KBK & KKNI & SKS & $\%$ \\
\hline $\begin{array}{l}\text { MK Pengembangan } \\
\text { Kepribadian (MPK) }\end{array}$ & $\begin{array}{l}\text { KPK (Kajian Pengembangan } \\
\text { Kepribadian) }\end{array}$ & 8 & 5.5 \\
\hline $\begin{array}{l}\text { MK Keilmuan dan Keterampilan } \\
\text { (MKK) }\end{array}$ & $\begin{array}{l}\text { KKK (Kajian Keterampilan } \\
\text { Kerja) }\end{array}$ & 12 & 8.2 \\
\hline MK Keahlian Berkarya (MKB) & $\begin{array}{l}\text { KKP (Kajian Cakupan } \\
\text { Keilmuan dan Pengetahuan) }\end{array}$ & 110 & 75.0 \\
\hline 1. English Language skills & 1. English Language skills & 58 & 39.7 \\
\hline $\begin{array}{l}\text { 2. English Language and } \\
\text { Literature }\end{array}$ & $\begin{array}{l}\text { 2. English Language and } \\
\text { Literature }\end{array}$ & 18 & 12.3 \\
\hline 3. English Language Teaching & $\begin{array}{l}\text { 3. English Language } \\
\text { Teaching }\end{array}$ & 16 & 12.3 \\
\hline 4. Research Components & 4. Research Components & 6 & 4.1 \\
\hline 5. Elective Courses & 5. Elective Courses & 12 & 8.2 \\
\hline MK Perilaku Berkarya (MPB) & $\begin{array}{l}\text { KMK (Kajian Metode dan } \\
\text { Tingkat Kemampuan) }\end{array}$ & 8 & 5.5 \\
\hline $\begin{array}{l}\text { MK Berkehidupan } \\
\text { Bermasyarakat (MBB) }\end{array}$ & $\begin{array}{l}\text { KKM (Kajian Pengembangan } \\
\text { Kemampuan Manajerial) }\end{array}$ & 8 & 5.5 \\
\hline & Tota & 146 & 100 \\
\hline
\end{tabular}

\section{METODE}

Penelitian ini menggunakan rancangan analisis isi dan pendekatan kualitatif untuk analisis data. Tujuan penelitian ialah untuk membuat rumusan kurikulum program sarjana Pendidikan Bahasa Inggris berbasis KKNI merujuk pada jenjang Kualifikasi $6 \mathrm{KKNI}$. Data penelitian meliputi kurikulum bahasa Inggris beberapa perguruan tinggi, yaitu: Universitas Negeri Malang, UNS, UNY, Universitas Mulawarman, IAIN Surakarta, IAIN Samarinda, Universitas Veteran Bangun Nusantara, dan Universitas Slamet Riyadi Surakarta. Dokumen kurikulum tersebut dianalisis isinya dan diidentifikasi aspek-aspek kurikulum, serta konten mata kuliah yang dicantumkan dalam setiap kurikulum. Untuk memperdalam pembahasan, peneliti juga melakukan wawancara mendalam dengan Kaprodi dan dosen di masing-masing perguruan tinggi baik secara langsung maupun melalui email. Berdasarkan hasil analisis dan perbandingan beberapa kurikulum tersebut, peneliti membuat simulasi kurikulum Pendidikan Bahasa Inggris yang dianggap ideal dengan mengacu pada ketentuan dalam SK Mendikbud baik dalam KBK maupun KKNI. Simulasi struktur isi kurikulum juga dikembangkan melalui workshop dan kebutuhan pengajaran.

\section{HASIL}

Hasil penelitian dikelompokkan ke dalam tiga katagori: rumusan learning outcomes, elemen kompetensi, dan sebaran MK dalam rentangan 146 sks. Learning outcomes terdiri dari learning outcomes Prodi dan learning outcomes mata kuliah. Berdasarkan kedua learning outcomes 
tersebut dikembangkanlah Profil Kemampuan Lulusan. Selanjutnya, elemen kompetensi dikembangkan berdasarkan kerangka pikir KBK dengan merujuk pada SK Dirjen Dikti No. 232/2000, SK Dirjen Dikti No. 045/2002 dan Pedoman Penyusunan Kurikulum Pendidikan Tinggi berbasis KKNI. Proses ini disajikan penyepadanan dalam KBK dan KKNI dari aspek pengelompokan bidang kajian. Adapun sebaran MK mengacu pada Standar Nasional Pendidikan Tinggi (Permendikbud No. 49 Tahun 2014) dan Penerapan KKNI bidang Pendidikan Tinggi (Permendikbud No. 73 Tahun 2013). Berdasarkan ketentuan ini sebaran MK dirumuskan sebagai berikut: (1) semester I dan II masing-masing 20 sks, (2) semester III sampai VI masing-masing 22 sks, dan (3) semester VII 18 sks. Pada semester VII sudah dijadwalkan penulisan skripsi sehingga mahasiswa memungkinkan bisa lulus pada semester VII.

\section{Pengembangan Learning Outcomes}

\section{Kajian Pengembangan Kepribadian}

Deskripsi learning outcomes pengembangan kepribadian dirumuskan berdasarkan Deskripsi Umum KKNI. MK pengembangan kepribadian meliputi Pancasila, PPKn, Pendidikan Agama seperti nampak pada Tabel 3, dikutip dari Solikhah (2015a:170-171).

\section{Kajian Keterampilan Kerja}

Kelompok Kajian Keterampilan Kerja diuraikan dari Parameter 1 KKNI, terdiri dari Learning Outcomes Prodi dan Learning Outcomes lulusan. Learning outcomes lulusan dikembangkan sendiri oleh penulis. Hasil rumusan disajikan pada Tabel 4 (Solikhah, 2015a:171-179).

\section{Kajian Cakupan Keilmuan dan Pengetahuan}

Cakupan kemendalaman keilmuan dan pengetahuan ialah Parameter $2 \mathrm{KKNI}$, menunjukkan sejauh mana lulusan menguasai konsep dan teori mengenai bidang ilmu yang didalami secara umum dan secara khusus. Rumusan learning outcomes disajikan pada Tabel 5 (Solikhah, 2015a:171-179).

\section{Kajian Metode dan Tingkat Kemampuan}

Metode dan tingkat kemampuan menunjukkan kualitas kemampuan lulusan dalam menangani permasalahan di bidang pekerjaannya dan bagaimana tahapan penyelesaian permasalahan bisa dilakukan. Rumusan learning outcomes disajikan dalam Tabel 6 (Solikhah, 2015a:171-179).

\section{Kajian Kemampuan Manajerial}

Kemampuan manajerial menunjukkan kualitas tanggungjawab dalam memimpin kelompok atau organisasi serta kemampuan melakukan supervisi dan evaluasi. Periksa Tabel 7 (Solikhah, 2015a:171-179). 
Pendidikan Bahasa Inggris Berbasis KKNI. Konstruktivisme, 8(1): 20-36.

Tabel 3. KPK (Kajian Pengembangan Kepribadian)

\begin{tabular}{|c|c|c|}
\hline No & Learning Outcomes & Mata Kuliah \\
\hline \multirow[t]{2}{*}{1} & DESKRIPSI GENERIK KKNI & \multirow{8}{*}{$\begin{array}{l}\text { 1. Pendidikan Agama } \\
\text { 2. Pendidikan Pancasila } \\
\text { 3. PPKn } \\
\text { 4. Bahasa Indonesia }\end{array}$} \\
\hline & $\begin{array}{l}\text { Sesuai dengan ideologi negara dan } \\
\text { budaya bangsa Indonesia, maka } \\
\text { implementasi sistem pendidikan nasional } \\
\text { dan sistem pelatihan kerja yang dilakukan } \\
\text { di Indonesia pada setiap jenjang kualifikasi } \\
\text { pada KKNI mencakup proses yang } \\
\text { membangun karakter dan kepribadian } \\
\text { manusia Indonesia sebagai berikut: }\end{array}$ & \\
\hline & $\begin{array}{l}\text { a. Bertaqwa kepada Tuhan Yang Maha } \\
\text { Esa }\end{array}$ & \\
\hline & $\begin{array}{l}\text { b. Memiliki moral, etika dan kepribadian } \\
\text { yang baik dalam menyelesaikan } \\
\text { tugasnya }\end{array}$ & \\
\hline & $\begin{array}{l}\text { c. Berperan sebagai warga negara yang } \\
\text { bangga } \\
\text { dan cinta tanah air serta mendukung } \\
\text { perdamaian dunia. }\end{array}$ & \\
\hline & $\begin{array}{l}\text { d. Mampu bekerja sama dan memiliki } \\
\text { kepekaan sosial dan kepedulian yang } \\
\text { tinggi terhadap masyarakat dan } \\
\text { lingkungannya. }\end{array}$ & \\
\hline & $\begin{array}{l}\text { e. Menghargai keanekaragaman budaya, } \\
\text { pandangan, kepercayaan, dan agama } \\
\text { serta pendapat/temuan original orang } \\
\text { lain. }\end{array}$ & \\
\hline & $\begin{array}{l}\text { f. Menjunjung tinggi penegakan hukum } \\
\text { serta memiliki semangat untuk } \\
\text { mendahulukan kepentingan bangsa } \\
\text { serta masyarakat luas. }\end{array}$ & \\
\hline
\end{tabular}


Tabel 4. Parameter 1: KKK (Kajian Keterampilan Kerja)

\begin{tabular}{|c|c|c|}
\hline No & Learning Outcomes Prodi & Learning Outcomes Lulusan \\
\hline & \multicolumn{2}{|c|}{$\begin{array}{l}\text { Deskripsi Spesifik: } \\
\text { Mampu mengaplikasikan bidang keahliannya dan memanfaatkan ilmu } \\
\text { pengetahuan, teknologi, dan/atau seni pada bidangnya dalam penyelesaian } \\
\text { masalah serta mampu beradaptasi terhadap situasi yang dihadapi. }\end{array}$} \\
\hline \multirow[t]{6}{*}{1} & $\begin{array}{l}\text { LO 6.1 } \\
\text { Mampu mengaplikasikan bidang } \\
\text { keahliannya dan memanfaatkan } \\
\text { ilmu pengetahuan, teknologi, } \\
\text { dan/atau seni pada bidangnya } \\
\text { dalam penyelesaian masalah serta } \\
\text { beradaptasi terhadap situasi yang } \\
\text { dihadapi. }\end{array}$ & $\begin{array}{l}\text { 1.1. Mampu mengajar bahasa Inggris } \\
\text { di tingkat SD, SMP, dan SMA } \\
\text { menggunakan bahasa Inggris sebagai } \\
\text { media komunikasi dengan } \\
\text { menggunakan bahan ajar dari buku } \\
\text { teks, media online, atau buatan sendiri } \\
\text { dan mampu memecahkan } \\
\text { permasalahan pembelajaran di } \\
\text { lapangan secara mandiri. }\end{array}$ \\
\hline & & $\begin{array}{l}1.2 \text { Mampu membuat, memodifikasi, } \\
\text { atau mengembangkan perangkat } \\
\text { pembelajaran bahasa Inggris: } \\
\text { kurikulum, silabus, bahan ajar, metode } \\
\text { mengajar, penilaian dan evaluasi dan } \\
\text { mengimpelemnasikan dalam proses } \\
\text { belajar dan pembelajaran di } \\
\text { lingkungan kerja maupun di } \\
\text { masyarakat secara mandiri. }\end{array}$ \\
\hline & & $\begin{array}{l}\text { 1.3. Mampu mempublikasikan hasil } \\
\text { pemikiran dan hasil karya mengenai } \\
\text { permasalahan pembelajaran bahasa } \\
\text { Inggris menggunakan bahasa Inggris } \\
\text { dan bahasa Indonesia secara terulis } \\
\text { dan lisan di lingkungan sendiri atau } \\
\text { masyarakat melalui seminar, media } \\
\text { cetak dan online. }\end{array}$ \\
\hline & & $\begin{array}{l}\text { 1.4. Mampu beradaptasi secara cepat } \\
\text { dalam lingkungan kerja dan berinisiatif } \\
\text { serta kreatif dalam melaksanakan } \\
\text { tugas secara mandiri atau kelompok. }\end{array}$ \\
\hline & & $\begin{array}{l}\text { 1.5. Mampu mengkomunikasikan } \\
\text { hasil karya, permasalahan } \\
\text { pembelajaran bahasa Inggris di } \\
\text { lapangan untuk mengatasi } \\
\text { permasalahan yang terjadi di } \\
\text { lapangan secara mandiri. }\end{array}$ \\
\hline & & $\begin{array}{l}\text { 1.6. Bersifat kritis, kreatif dan tanggap } \\
\text { dalam mengidentifikasi masalah } \\
\text { pembelajaran bahasa Inggris di } \\
\text { lapangan dan menawarkan alternatif } \\
\text { solusi yang relevan dengan keilmuan } \\
\text { dan konteks permasalahan lapangan. }\end{array}$ \\
\hline
\end{tabular}


Tabel 5. Parameter 2: KKP (Kajian Keilmuan dan Pengetahuan)

\begin{tabular}{|c|c|c|}
\hline No & Learning Outcomes Prodi & Learning Outcomes Lulusan \\
\hline 1 & \multicolumn{2}{|c|}{$\begin{array}{l}\text { Deskripsi Spesifik: } \\
\text { Menguasai konsep teoritis bidang pengetahuan tertentu secara umum } \\
\text { dan konsep teoritis bagian khusus dalam bidang pengetahuan } \\
\text { tersebut secara mendalam serta mampu memformulasikan } \\
\text { penyelesaian masalah prosedural. }\end{array}$} \\
\hline \multirow[t]{4}{*}{2} & $\begin{array}{l}\text { LO } 6.2 \\
\text { Menguasai konsep teoritis } \\
\text { belajar pembelajaran, design } \\
\text { pembelajaran, ilmu bahasa, } \\
\text { sastra, keterampilan berbahasa } \\
\text { Inggris, pemecahan masalah } \\
\text { pembelajaran bahasa Inggris } \\
\text { dan konsep lain untuk } \\
\text { menguatkan penyelesaian } \\
\text { masalah dan pekerjaan bidang } \\
\text { pembelajaran bahasa Inggris. }\end{array}$ & $\begin{array}{l}\text { 2.1. Memiliki pengetahuan konsep } \\
\text { teoritis belajar pembelajaran dan } \\
\text { design pembelajaran bidang } \\
\text { bahasa Inggris yang meliputi: } \\
\text { kurikulum, bahan ajar, metode } \\
\text { mengajar, penilaian, pengelolaan } \\
\text { kelas dan konsep pendukung yang } \\
\text { relevan untuk bahan pengambilan } \\
\text { putusan secara praktis, kreatif dan } \\
\text { inovatif di lapangan. }\end{array}$ \\
\hline & & $\begin{array}{l}2.2 \text { Memiliki pengetahuan teoritis } \\
\text { mengenai ilmu bahasa yang } \\
\text { meliputi linguistik, sastra dan } \\
\text { bahasa terapan seperti } \\
\text { sosiolinguistik, analisis wacana, } \\
\text { pragmatik dan literasi berbahasa } \\
\text { Inggris yang tercakup dalam } \\
\text { keterampilan berbahasa Inggris } \\
\text { dan ilmu pendukung lain yang } \\
\text { relevan dengan proses } \\
\text { pembelajaran dan pengembangan } \\
\text { perangkat pembelajaran bahasa } \\
\text { Inggris serta mecehana masalah di } \\
\text { lapangan. }\end{array}$ \\
\hline & & $\begin{array}{l}\text { 2.3. Mampu mengkomunikasikan } \\
\text { konsep teoritis mengenai } \\
\text { permasalahan pembelajaran, } \\
\text { perangkat pembelajaran, } \\
\text { kebahasaan, metode } \\
\text { pembelajaran dan alternatif } \\
\text { solusinya kepada siswa, guru, } \\
\text { maupun masyarakat pengguna } \\
\text { lisan atau tertulis. }\end{array}$ \\
\hline & & $\begin{array}{l}\text { 2.4. Memiliki konsep teoritis } \\
\text { mengenai penilaian dan evaluasi } \\
\text { pembelajaran Bahasa Inggris } \\
\text { untuk pedoman pengembangan } \\
\text { perangkat penilaian, evaluasi, dan }\end{array}$ \\
\hline
\end{tabular}


Tabel 6. Parameter 3: KMK (Kajian Metode dan Tingkat Kemampuan)

\begin{tabular}{|c|c|c|}
\hline No & Learning Outcomes Prodi & Learning Outcomes Lulusan \\
\hline 1 & \multicolumn{2}{|c|}{$\begin{array}{l}\text { Deskripsi Spesifik: } \\
\text { Mampu mengambil keputusan yang tepat berdasarkan analisis } \\
\text { informasi dan data, dan mampu memberikan petunjuk dalam memilih } \\
\text { berbagai alternatif solusi secara mandiri dan kelompok. }\end{array}$} \\
\hline \multirow[t]{5}{*}{2} & $\begin{array}{l}\text { LO } 6.2 \\
\text { Mampu mengidentifikasi } \\
\text { permasalahan dari berbagai } \\
\text { sumber dan beragam jenis data } \\
\text { dan bisa bekerja sama serta } \\
\text { berkomunikasi secara efektif } \\
\text { dalam sebuah kelompok baik } \\
\text { sebagai anggota atau pimpinan } \\
\text { kelompok, untuk menyelesaikan } \\
\text { pekerjaan bidang pembelajaran } \\
\text { bahasa Inggris dan } \\
\text { mendokumentasikan hasil } \\
\text { pekerjaan dalam bentuk laporan } \\
\text { tertulis. }\end{array}$ & $\begin{array}{l}\text { 3.1. Mampu menerapkan proses } \\
\text { pengambilan data dan informasi } \\
\text { secara ilmiah dan objektif } \\
\text { menggunakan berbagai teknik } \\
\text { pengumpulan data untuk bahan } \\
\text { analisis dan pengambilan } \\
\text { simpulan secara objektif dan } \\
\text { benar. }\end{array}$ \\
\hline & & $\begin{array}{l}\text { 3.2. Mampu menyesuaikan diri } \\
\text { dengan cepat di lingkungan kerja, } \\
\text { mengambil keputusan secara } \\
\text { objektif dan dapat bekerjasama } \\
\text { dalam kerja kelompok } \\
\text { (teamwork). }\end{array}$ \\
\hline & & $\begin{array}{l}\text { 3.3. Mampu menyiapkan laporan } \\
\text { tertulis tentang hasil pekerjaan } \\
\text { baik yang menjadi tanggungjawab } \\
\text { sendiri maupun tanggungjawab } \\
\text { kelompok, mengenai analisis, } \\
\text { rancangan, maupun implementasi } \\
\text { suatu program pembelajaran. }\end{array}$ \\
\hline & & $\begin{array}{l}\text { 3.4. Mampu menerapkan teknik- } \\
\text { teknik komunikasi individu dan } \\
\text { komunikasi kelompok secara } \\
\text { efektif. }\end{array}$ \\
\hline & & $\begin{array}{l}\text { 2.5. Mampu menerapkan etika } \\
\text { pergaulan, norma agama, norma } \\
\text { sosial, dan etika dan menghargai } \\
\text { keragaman pendapat, } \\
\text { kekurangan dan kelebihan setiap } \\
\text { anggota kelompok di lingkungan } \\
\text { kerja. }\end{array}$ \\
\hline
\end{tabular}


Tabel 7. Parameter 4: KKM (Kajian Kemampuan Manajerial)

\begin{tabular}{|c|c|c|}
\hline No & Learning Outcomes Prodi & Learning Outcomes Lulusan \\
\hline 1 & \multicolumn{2}{|c|}{$\begin{array}{l}\text { Deskripsi Spesifik: } \\
\text { Bertanggung jawab pada pekerjaan sendiri dan dapat diberi tanggung } \\
\text { jawab atas capaian hasil kerja organisasi. }\end{array}$} \\
\hline \multirow[t]{6}{*}{2} & $\begin{array}{l}\text { LO } 6.4 \\
\text { Mampu melakukan evaluasi dan } \\
\text { supervisi terhadap capaian hasil } \\
\text { kerja di bidang pembelajaran } \\
\text { bahasa Inggris yang menjadi } \\
\text { tanggungjawabnya baik sebagai } \\
\text { anggota atau pimpinan dalam } \\
\text { kelompok kerja. }\end{array}$ & $\begin{array}{l}\text { 4.1. Mampu melakukan evaluasi } \\
\text { terhadap pekerjaan yang menjadi } \\
\text { tanggungjawab sendiri dan } \\
\text { sebagai pimpinan kelompok. }\end{array}$ \\
\hline & & $\begin{array}{l}\text { 4.2. Memiliki sikap kritis, kreatif, } \\
\text { inovatif dan disiplin tinggi dalam } \\
\text { bekerja secara mandiri maupun } \\
\text { kelompok serta menunjung tinggi } \\
\text { norma akademik, etika dan } \\
\text { keragaman pendapat, agama, } \\
\text { etnis, dan kepribadian anggota } \\
\text { tim. }\end{array}$ \\
\hline & & $\begin{array}{l}\text { 4.3. Mampu melakukan supervisi } \\
\text { dan evaluasi terhadap pekerjaan } \\
\text { yang menjadi tanggungjawab } \\
\text { kelompok kerja yang dipimpinnya. }\end{array}$ \\
\hline & & $\begin{array}{l}\text { 4.4. Mampu menganalisis } \\
\text { permasalahan dengan cepat untuk } \\
\text { menemukan solusi dengan } \\
\text { mengedepankan kebersamaan, } \\
\text { tanggungjawab, dan keberagaman } \\
\text { anggota tim. }\end{array}$ \\
\hline & & $\begin{array}{l}\text { 4.5. Mampu menyusun laporan } \\
\text { tertulis dan lisan dan } \\
\text { mengkomunikasikan isi laporan } \\
\text { dengan tim dan lingkungan kerja } \\
\text { secara pribadi dan penanggung } \\
\text { jawab organisasi. }\end{array}$ \\
\hline & & $\begin{array}{l}\text { 1.6. Mampu menggerakkan } \\
\text { dinamika kelompok dan partisipasi } \\
\text { aktif anggota kelompok sampai } \\
\text { tujuan organisasi berhasil dengan } \\
\text { penuh tanggung jawab. }\end{array}$ \\
\hline
\end{tabular}

\section{Proporsi Beban Kredit Matakuliah}


Sesuai SK Mendiknas No. 232/U/2000 dan SK Mendiknas No. 045/U/2002 jumlah beban kredit program sarjana ialah 144 sks. Pengelompokan bidang kajian mengikuti struktur Parameter KKNI. Besaran SKS setiap matakuliah merujuk pada kemendalaman, keluasan, dan jumlah waktu yang diperlukan untuk mencapai learning outcomes matakuliah. Proporsi kelompok bidang kajian disajikan dalam Tabel 8 (Solikhah, 2015a:180).

Tabel 8. Proporsi SKS Kurikulum Sarjana Pendidikan Bahasa Inggris

\begin{tabular}{llrrr}
\hline No & \multicolumn{1}{c}{ Kelompok Bahan Kajian } & SKS & \multicolumn{1}{c}{$\%$} \\
\hline 1 & KPK (Kajian Pengembangan Kepribadian) & 8 & $\mathbf{5 . 5}$ \\
\hline 2 & KKK (Kajian Keterampilan Kerja) & 12 & $\mathbf{8 . 2}$ \\
\hline 3 & KKP (Kajian Keilmuan dan Pengetahuan) & 58 & $\mathbf{7 5 . 0}$ \\
\hline & 1. English Language skills & 18 & 12.3 \\
\hline & 2. English Language and Literature & 16 & 12.3 \\
\hline & 3. English Language Teaching & 6 & 4.1 \\
\hline & 4. Research Components & 12 & 8.2 \\
\hline & 5. Elective Courses & 8 & $\mathbf{5 . 5}$ \\
\hline 4 & KMK (Kajian Metode dan Tingkat Kemampuan) & 8 & $\mathbf{5 . 5}$ \\
\hline 5 & KKM (Kajian Kemampuan Manajerial) & Total & $\mathbf{1 4 6}$ & $\mathbf{1 0 0}$ \\
\hline
\end{tabular}

Jenis matakuliah dan beban SKS dalam struktur kurikulum yang dikembangkan ini juga mempertimbangkan aspek IPTEKS yang sedang dikembangkan dan yang akan datang. Literasi akademik bidang komputer dimasukkan sebagai kompetensi. Computer Literacy mengajarkan aplikasi words, excel, power point, web, corel draw, dan photoshop, yang mendukung untuk analisis data penelitian, publikasi karya ilmiah dan pengembangan perangkat pembelajaran. Selanjutnya, Introduction to Journal Article Writing dan Trends and Issues in ELT diberikan untuk komponen IPTEKS ke depan dan Research Statistics untuk IPTEKS yang dikembangkan (Solikhah, 2015a:181).

Tabel 9. Jenis Matakuliah dan Beban SKS Menurut Bidang Kajian

\begin{tabular}{|l|l|r|r|}
\hline No & Kelompok Bahan Kajian & SKS & \% \\
\hline 1 & KPK (Kajian Pengembangan Kepribadian) & $\mathbf{8}$ & $\mathbf{5 . 4 8}$ \\
& 1. Pendidikan Agama & 2 & \\
& 2. Pendidikan Pancasila & 2 & \\
& 3. Pendidikan Kewarganegaraan & 2 & \\
& 4. Bahasa Indonesia & 2 & \\
\hline 2 & KKK (Kajian Keterampilan Kerja) & $\mathbf{1 0}$ & $\mathbf{6 . 8 5}$ \\
& 1. Filsafat Ilmu & 2 & \\
& 2. Belajar dan Pembelajaran & 2 & \\
& 3. Pengantar IImu Pendidikan & 2 & \\
& 4. Perkembangan Peserta Didik & 2 & \\
& 5. Profesi Keguruan & $0 / 2$ & \\
\hline
\end{tabular}


Solikhah, Imroatus. 2016. Pengembangan Model Kurikulum

Pendidikan Bahasa Inggris Berbasis KKNI. Konstruktivisme, 8(1): 20-36.

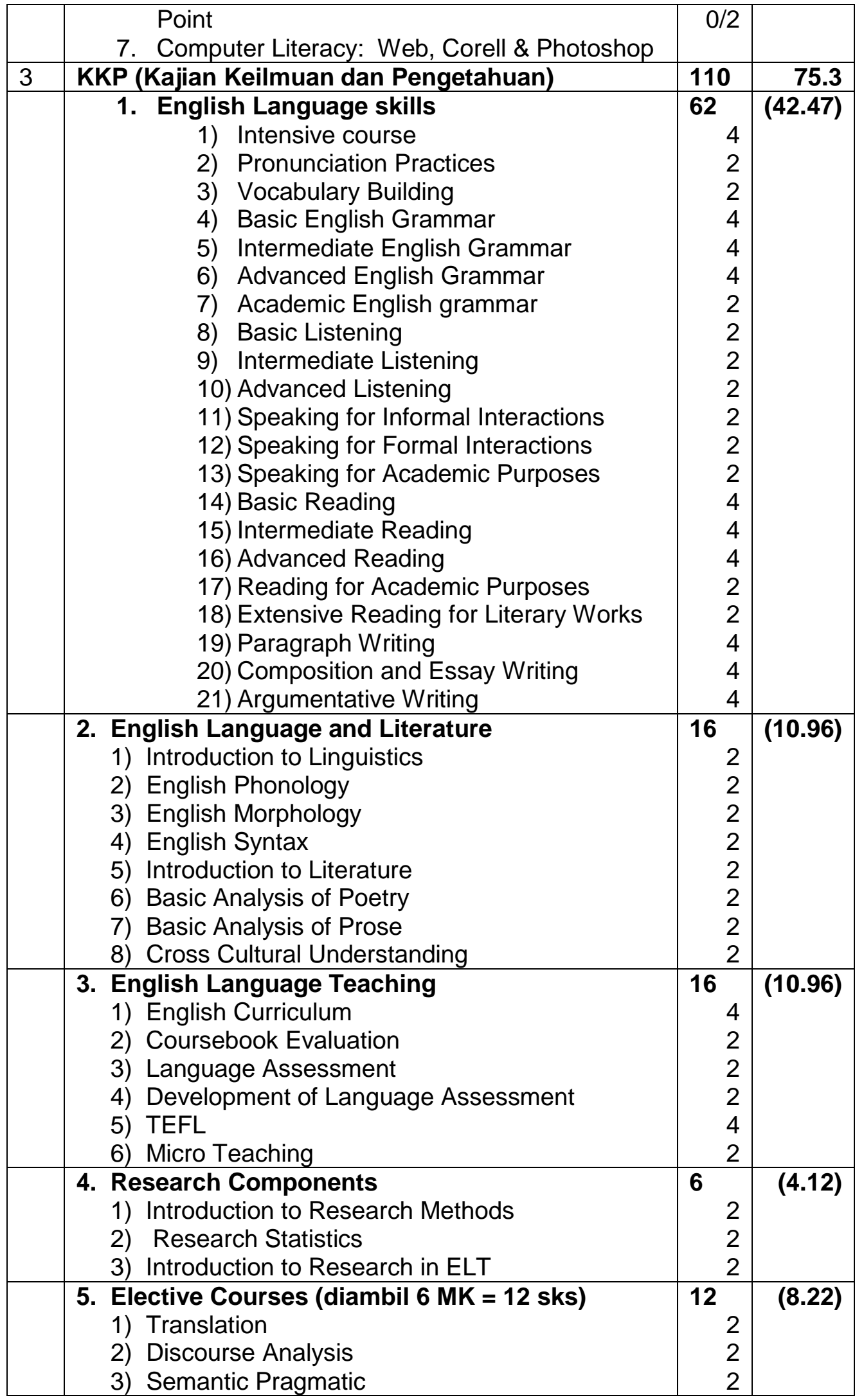




\begin{tabular}{|l|l|r|r|}
\hline & 4) ESP/EAP & 2 & \\
& 5) TEYL & 2 & \\
& 6) Introduction to Business English & 2 & \\
& 7) Instructional Material Development & 2 & \\
& 8) Translation for Literary works & 2 & \\
& 9) Applied linguistics & 2 & \\
& 10) Trends \& Issues in Language Teaching & 2 & \\
& 11) Language teaching media & 2 & \\
\hline 4 & KMK (Kajian Metode dan Tingkat Kemampuan) & $\mathbf{8}$ & 5.48 \\
& 1) Seminar on Thesis Proposal & 2 & \\
& 2) Sarjana Thesis & 6 & \\
\hline 5 & KKM (Kajian Kemampuan Manajerial) & $\mathbf{8}$ & 5.48 \\
& 1) PPL Keguruan & 4 & \\
\hline & 2) KKN & 4 & \\
\hline
\end{tabular}

\section{Sebaran Matakuliah Menurut Semester}

Sebaran matakuliah tiap semester menurut Pedoman Kuirkulum KKNI ialah semester I dan semester II masing-masing 20 sks, dan semester III sampai semester VI masing-masing 22 sks. Semester VII maksimal 18 sks untuk memberi kesempatan mahasiswa menulis skripsi. Proporsi beban kredit setiap semester disajikan berikut ini.

\section{SEMESTER I \& II}

\begin{tabular}{|l|l|r|l|r|}
\hline \multicolumn{2}{|c|}{ SEMESTER I } & & SEMESTER II \\
\hline 1 & Intensive English Course & 4 & Profesi Keguruan & 2 \\
\hline 2 & Pronunciation practices & 2 & Belajar dan Pembelajaran & 2 \\
\hline 3 & Vocabulary buliding & 2 & Intermediate English Grammar & 2 \\
\hline 4 & Basic English grammar & 2 & Basic Listening & 2 \\
\hline 5 & Pendidikan Agama & 2 & Speaking for Informal Interaction & 2 \\
\hline 6 & Pendidikan Pancasila & 2 & Literal reading & 4 \\
\hline 7 & PPKn & 2 & Paragraph writing & 4 \\
\hline 8 & Pengantar IImu Pendidikan & 2 & Filsafat Ilmu & 2 \\
\hline 9 & $\begin{array}{l}\text { Perkembangan Peserta } \\
\text { Didik }\end{array}$ & 2 & $\begin{array}{l}\text { Computer Literacy: Web, Corel, } \\
\text { Photoshop }\end{array}$ & $0 / 2$ \\
\hline 10 & $\begin{array}{l}\text { Computer Literacy: Words, } \\
\text { Excel, Power Point }\end{array}$ & $0 / 2$ & & 20 \\
\hline & & 20 & & \\
\hline
\end{tabular}

\section{SEMESTER III \& IV}

\begin{tabular}{|l|l|r|l|r|}
\hline \multicolumn{2}{|c|}{ SEMESTER III } & 4 & Academic English Grammar & 2 \\
\hline 1 & $\begin{array}{l}\text { Advanced English } \\
\text { Grammar }\end{array}$ & 2 & Advanced Listening & 2 \\
\hline 2 & Intermediate Listening & 2 & Speaking for Academic Purposes & 2 \\
\hline 3 & Speaking for Formal Setting & 2 & Advanced Reading & 4 \\
\hline 4 & Intermediate Reading & 4 & Argumentative Writing & 2 \\
\hline 5 & $\begin{array}{l}\text { Composition \& Essay } \\
\text { Writing }\end{array}$ & & & \\
\hline
\end{tabular}


Solikhah, Imroatus. 2016. Pengembangan Model Kurikulum

Pendidikan Bahasa Inggris Berbasis KKNI. Konstruktivisme, 8(1): 20-36.

\begin{tabular}{|l|l|r|l|r|}
\hline 6 & Introduction to Linguistics & 2 & English Curriculum & 4 \\
\hline 7 & Introduction to Literature & 2 & Introduction to Research Methods & 2 \\
\hline 8 & $\begin{array}{l}\text { Cross Cultural } \\
\text { Understanding }\end{array}$ & 2 & English Phonology & 2 \\
\hline 9 & $\begin{array}{l}\text { Bahasa Indonesia } \\
\text { Keilmuan }\end{array}$ & 2 & Sociolinguistics & 2 \\
\hline & \multicolumn{2}{|}{ Total } & $\mathbf{2 2}$ & \\
\hline
\end{tabular}

SEMESTER V \& VI

\begin{tabular}{|l|l|r|l|r|}
\hline \multicolumn{2}{|c|}{ SEMESTER V } & SEMESTER VI \\
\hline 1 & English morphology & 2 & English Syntax & 2 \\
\hline 2 & Basic analysis of poetry & 2 & Basic analysis of prose & 2 \\
\hline 3 & TEFL & 4 & Seminar on thesis proposal & 2 \\
\hline 4 & $\begin{array}{l}\text { Language Learning } \\
\text { Assessment }\end{array}$ & 2 & $\begin{array}{l}\text { Language Assessment } \\
\text { Development }\end{array}$ & 2 \\
\hline 5 & Research statistics & 2 & Coursebook Evaluation & 4 \\
\hline 6 & Research method in ELT & 4 & Extensive Reading for Literature & 2 \\
\hline 7 & $\begin{array}{l}\text { Reading for academic } \\
\text { purposes }\end{array}$ & 2 & Micro Teaching & 2 \\
\hline 8 & Translation* & 2 & Intro to Journal Writing \\
\hline 9 & Discourse analysis* & 2 & ESP/EAP* & 2 \\
\hline 10 & Semantic-Pragmatics $^{*}$ & 2 & Trends \& Issues in ELT & 2 \\
\hline & dipilih 2MK $=4$ sks $^{*}$ 22 & "dipilih 2 MK =4 sks & 2 \\
\hline
\end{tabular}

SEMESTER VII \& VIII

\begin{tabular}{|r|l|r|l|r|}
\hline \multicolumn{2}{|c|}{ SEMESTER VII } & SEMESTER VIII \\
\hline 1 & Elective course *2 MK & 4 & Thesis & 6 \\
\hline 2 & PPL & 4 & & \\
\hline 3 & KKN & 4 & & \\
\hline 4 & Thesis & 6 & & \\
\hline & & $\mathbf{1 8}$ & & \\
\hline
\end{tabular}

\section{BAHASAN}

Rumusan learning outcomes dalam kurikulum berbasis KKNI merupakan indikator penting bagaimana Prodi dan matakuliah akan dikembangkan melalui learning outcomes Prodi dan learning outcomes matakuliah. Learning outcomes Prodi mengikuti rumusan indikator KKNI yang mengacu pada deskripsi umum untuk matakuliah pengembangan kepribadian dan deskripsi spesifik untuk kelompok kajian elemen kompetensi.

Learning outcomes matakuliah dikembangkan sendiri oleh peneliti sebagai acuan pengembangan. Secara cermat peneliti telah mengkaji makna dalam indikator KKNI, yaitu: Pengembangan Kepribadian, Keterampilan kerja, Cakupan keilmuwan dan keterampilan, metode dan kemampuan, dan kemampuan manajerial. Learning outcomes setiap kelompok kajian yang merupakan elemen kompetensi telah dirumuskan dengan mengacu pada prinsip kurikulum dalam menyusun goal, objectives, kompetensi, dan capaian yang akan diperoleh pembelajar jika suatu matakuliah sudah selesai (Solikhah, 2015b). Learning outcomes dalam 
konteks KKNI juga menunjukkan kualitas kompetensi yang akan dicapai pembelajar. Di berbagai negara, kualifikasi nasional telah dirumuskan secara spesifik untuk disiplin ilmu tertentu, misalnya Kualifikasi Guru Bahasa Inggris. Di Indonesia, rumusan kualifikasi ditetapkan sendiri dalam learning outcomes Prodi sehingga rumusan learning outcomes harus dibuat secara cermat dan teliti serta memungkinkan terjaminnya quality control secara baik (Brown, 2011).

Kelompok kajian inti keilmuan Prodi memiliki tujuan pengembangan keilmuan dan keterampilan bidang Pengajaran Bahasa Inggris. Untuk itu, kelompok kajian ini dipecah ke dalam enam kelompok, yaitu: (1) languase skills, (2) linguistics, (3) literature, (4) teaching, (5) research, dan (6) knowledge contents. Model ini telah diterapkan secara mantap di Universitas Negeri Malang (UM) dan terbukti efektif untuk memudahkan pengelompokan bahan kajian dan menetapkan proporsi matakuliah di setiap kelompok. Dari sini juga mudah diketahui berapa proporsi untuk penguat keterampilan dan bidang ilmu dilihat dari besaran sks. Proporsi yang tepat merupakan quality assurance bahwa lulusan akan memiliki learning outcomes yang bisa diandalkan. Beberapa kurikulum lain yang dikaji tidak proporsional menyusun struktur matakukiah bahkan ada yang tidak saling menguatkan antara kelompok kajian satu dengan kelompok kajian lainnya. Pengelompokan bidang kajian seperti di UM juga memudahkan penyusun kurikulum dalam menentukan kelompok matakuliah mana yang termasuk ke dalam Pengembangan Kepribadian, Keterampilan kerja, Keilmuan dan keterampilan, Metode dan tingkat kemampuan, dan Kemampuan manajerial.

Struktur isi kurikulum dalam penelitian ini mempertimbangkan berbagai hal. Dalam kelompok matakuliah skills, disadari bahwa mahasiswa masukan tidak memiliki kemampuan berbahasa Inggris yang setara dan bekal yang diperoleh sewaktu di SMA belum memadai, Untuk itu, pada semester awal diberikan intensive course, vocabulary building, dan pronunciation practices. Matakuliah ini bertujuan untuk memberi landasan keterampilan berbahasa Inggris tingkat awal.

Untuk menjaga keberlangsungan praktik berbahasa Inggris, susunan matakuliah skills dibuat sedemikian rupa. Matakuliah reading dijadwalkan sampai semester kelima dengan bobot sks lebih dan keterampilan menulis diberikan dalam tiga semester denganbibot sks tiap semester 4 sks. Dalam konteks EFL, membaca dan menulis diposisikan sebagai syarat mencapai literasi akademik sehingga bobotnya perlu ditambah (Solikhah, 2015c).

Matakuliah penguat untuk pengajaran, pengembangan keilmuan, dan pengetahuan ilmu bahasa dan ilmu pembelajaran disusun cukup cermat memperhatikan trend dan isu terkini dalam pembelajaran bahasa Inggris. Karena itu, matakuliah linguistik, sastra, pengisi keilmuan, riset dan pengajaran diberi bobot lebih. Khusus matakuliah pengisi keilmuan, dipilih matakuliah yang angsung memberi penguatan pengetahuan ilmu bahasa, seperti translation, discourse analysis, pragmatics, dll. Matakuliah ini wajib ditempuh, namun berhubung jumlahnya banyak, matakuiah ini ditawarkan dalam bentuk matakuliah pilihan (Budiharso, 2015). 
Solikhah, Imroatus. 2016. Pengembangan Model Kurikulum

Pendidikan Bahasa Inggris Berbasis KKNI. Konstruktivisme, 8(1): 20-36.

Dilihat dari pengelompokan bidang kajian, jumlah sks dalam satu program, sebaran matakuliah setiap semester dan komposisi menurut ketentuan Mendikbud, kurikulum ini sudah cukup ideal. Jika kurikulum ini diadopsi untuk diterapkan di suatu lembaga, tidak memerlukan penyesuaian yang rumit; cukup disesuaikan beberapa istilah dan jika ada matakuliah yang tidak sesuai, tinggal diganti namanya saja.

\section{SIMPULAN}

Pengembangan kuirkulum berbasis $\mathrm{KKNI}$ mengharuskan penyusun untuk melakukan penyesuaian dengan KBK. Ketentuan jumlah sks, elemen kompetensi, dan jenis matakuliah dalam penyusunan Kurikulum Berbasis KKNI tetap mengacu pada SK Mendiknas No. 232/U/2000 dan SK Mendiknas No. 045/U/2002. Istilah elemen kompetensi dalam KBK harus disepadankan dengan deskriptor dalam KKNI. Rumusan kurikulum KKNI dimulai dari penyusunan learning outcomes Prodi dan learning outcomes matakuliah. Rumusan itu memerlukan kerja keras dari perguruan tinggi melalui Prodi. Rumusan kurikulum Sarjana Pendidikan Bahasa Inggris dalam penelitian ini dikembangkan dengan membandingkan berbagai kurikulum perguruan tinggi sehingga rumusannya bisa diandalkan. Sebaran MK menurut semester sesuai dengan Permendikbud No. 49 Tahun 2014 tentang Standar Nasional Pendidikan Tinggi Pasal 17 Ayat (1) sampai Ayat (7) memberi petunjuk semester I \& II = 20 sks, semester III-IV $=22 \mathrm{sks}$, semester VII = 18 sks termasuk skripsi dengan total 146 sks.

\section{DAFTAR RUJUKAN}

Budiharso, Teguh. 2015. Reorientasi Kurikulum Pendidikan Bahasa Inggris Berbasis KKNI IAIN Surakarta. Makalah Seminar. Surakarta: Pusat Kajian Bahasa dan Budaya.

Depdiknas. 2010. Buku Pedoman Kerangka Kualifikasi Nasional Indonesia. Jakarta: Direktorat Jendral Pendidikan Tinggi.

Despdiknas. 2012. Panduan Penyusunan Kurikulum Pendidikan Tinggi. Jakarta: Dirjen Dikti.

Johnson, Steve, Veith, Sarah, Dewiyati, Silvia. 2015. A Framework to embed communication skills across the curriculum: a design-based research approach. Journal of University Teaching \& Learning Practice, 12(4):1-14.

Kepmendiknas No. 045/U/2002 tentang Kurikulum Inti Perguruan Tinggi.

Kepmendiknas. No. 232/U/2000 tentang Pedoman Penyusunan Kurikulum PT dan Penilaian Hasil Belajar Mahasiswa.

Peraturan Presiden Nomor 8 Tahun 2012. Kerangka Kualifikasi Nasional Indonesia. Jakarta: Sekretariat Negara.

Peraturan Pemerintha RI No. 4 Tahun 2014 tentang Penyelenggaraan Pendidikan Tinggi dan Pengelolaan Perguruan Tinggi.

Permendikbud No. 49 Tahun 2014 tentang Standar Nasional Pendidikan Tinggi.

Permendikbud No. 73 Tahun 2013 tentang Penerapan Kerangka Kualifikasi Nasional bidang Pendidikan Tinggi.

Permendikbud No. 87 Tahun 2014 tentang Akreditasi Program Studi Perguruan Tinggi. 
Permendikbud No. 50 Tahun 2014 tentang Sistem Penjaminan Mutu Pendidikan Tinggi.

Undang-Undang Republik Indonesia No. 12 Tahun 2012 tentang Pendidikan Tinggi.

Salim, Khalid. 2012. English Language Curriculum in Oman. International Journal of English Linguistics, 2(5):40-44.

SK Dirjen Dikti No. 43/DIKTI/Kep/2006 tentang Rambu-Rambu Pelaksanaan Kelompok Mata Kuliah Pengembangan Kepribadian di Perguruan Tinggi.

Solikhah, Imroatus. 2015a. Learning Outcomes Berbasis KKNI dalam Kurikulum Pendidikan Bahasa Inggris. Surabaya: Penerbit Jenggala Pustaka Utama.

Solikhah, Imroatus. 2015b. Designing Academic Literacy of EAP Program for Indonesian Learners. International Journal of Language and Literature, 6(2):34-37.

Solikhah, Imroatus. 2015c. KKNI dalam Kurikulum Berbasis Learning Outcomes. Lingua, Jurnal Bahasa Sastra dan Pengajarannya. 12(1):1-22. www.jurnal-lingua.info

Universitas Negeri Malang. 2013. Peraturan Dekan Fakultas Sastra No. 7 Tahun 2014. Tentang Standar Kompetensi Lulusan dan Kurikulum Program Studi pada Jurusan Sastra Inggris, Fakultas Sastra. Malang: Fakultas Sastra. 